\title{
The Price of Prayer
}

\author{
Kurt Appel
}

\section{Prayer and God's Heavenly Palace}

The question of prayer, in my view, is the most difficult and fundamental theological issue of our time.

In his book on religion, Jacques Derrida points out that there is no place for prayer within the conceptual worlds of onto-theology, whose last representative is Hegel. ${ }^{1}$ In fact, the symbolic order that has prevailed for centuries if not millennia that centers around God through prayer, seems to have collapsed.

In his great commentary on the apostle Paul's Letter to the Romans, U. Wilckens writes that Paul's real reason for composing this text was that in a situation in which the unity of the gospel was at stake, Paul wanted to assure himself of the prayer of the church in Rome. ${ }^{2}$ The mighty voice of the Roman congregation was to penetrate into God's heavenly palace, prompting him to prioritize the apostle's now reinforced prayer.

If we imagine a cartography of prayer, then at first sight we appear to be confronted with two different orders. On the one hand, there is our earth and the worshiper, or the community of worshipers. On the other hand, there is "heaven", the addressee of these prayers, which is influenced by them and intervenes correctively, helpfully and sometimes punitively on this earth. It is never certain whether an event is due to prayer or occurs or would have occurred quasi "naturally" and it is also unclear how the temporality of prayer and the eternity of God relate to one another. This led the wily Leibniz to suppose that our prayers have already been factored in the providence of God.

If we take a closer look at the spatial order of prayer we find that there were always places, times, spheres and individuals where heaven and earth converged. God's heavenly palace extended to the priestly and parental blessing, to ecclesiastical and liturgical buildings and times, to books such as the Psalter and the Breviary, to musical productions and ultimately to the hearts of the people praying.

1 J. Derrida, "Faith and Knowledge. The Two Sources of 'Religion' at the Limits of Reason Alone", in: J. Derrida and G. Vattimo, Religion, Stanford 1998.

2 U. Wilckens, Der Brief an die Römer. 3. Teilband. Röm12-16(EKKVI/3), Zürich / Braunschweig ${ }^{2} 1989,128-130$. 
Later I will come back to the fact that the geography of heaven and prayer is more complex than implied in this introductory sketch. But for now what is most important is an experience that has had so far too little impact on theology and philosophy - Nietzsche in all his genius is an exception - and even less in psychoanalysis (with certain exceptions such as Lacan), historical research and sociology. I am referring to the massive trauma suffered by the west through the loss of the heavenly palace and the associated emptiness of prayer. This trauma, subject to brilliant literary depiction, first in embryonic form in the work of Jean Paul ${ }^{3}$ and later at full tilt in the writings of Dostoevsky and Nietzsche, is bound up with a profound upheaval in the symbolic order (outlined in this volume by Deibl and Guanzini). This order was previously geared towards a transcendent "you" that was localized and centered in the terminus of "heaven". But with the loss of the heavenly palace it began to circle around an emptiness, one that threatens to devour all potential for meaning.

I suspect one of the reasons why the West is often regarded with hostility in many so-called premodern cultures is that this emptiness inspires fear. In the West the act of prayer, the foundation of understanding and doing in many cultures, has been cut off from its addressee. We might also make the passing observation that the Catholic Church clings to a concrete localization of the divine - for instance in the form of the tabernacles that can be found in every Catholic church building - which distinguishes it from Protestantism and may actually represent the true chasm between the two denominations today.

Scripture includes a book that tells with unsurpassed drama of the loss of the divine addressee, namely the Book of Ezekiel. ${ }^{4}$ The introductory chapter relates how Ezekiel, to whom "the heavens were opened" (Ez 1:1), beholds the glory of YHWH, the ruler above the cherubs; a second encounter with the cherubs and the glory of YHWH follows in chapters 8-10. This time the heaven is not opened in the plain of the river Chebar in Babylon. Rather, the prophet is transported to the temple in Jerusalem through a vision. So the localization is more complex than in the introductory chapter, where the heavenly palace

3 See Jean Paul's famous “The Dead Christ Proclaims That There is No God", under: http://www. gutenberg.org/files/36164/36164-h/36164-h.htm.

4 An impressive commentary has been provided by M. Greenberg, Ezekiel 1-20, New Haven 2007, 193-239. The Exodus of the Presence of God from the Temple prepares its destruction. The following earthly judgment on Jerusalem and its temple is already celestially prescribed. However, the Ezekiel book emphasizes that there is a - at least diminished - presence of God in the exile community for which YHWH is a "small sanctuary" (Ezekiel 11:16). This exile community will be given a "heart of flesh" instead of the "heart of stone" (Ezekiel 11:19) so that YHWH will be their God and Israel will be His people. 
begins to touch the prophet in the plain. In this case the precondition for the encounter between heaven and earth is a transportation, a dis-placement of the prophet, who relates how, in "visions of God he took me to Jerusalem, to the entrance of the north gate of the inner court" (Ez 8:3). The heavenly palace connects with the real site of the temple in Jerusalem, not directly, but through the vision of the ruptured (dis-located) prophet.

The scene is thus located between heaven and earth, dream and reality, Babylon and Jerusalem and future and past in the sense that, within the framework of the vision, the prophet looks back on a future event (the killing of the idolaters). But the thrust of the vision is the abbondonement from the temple by the glory of YHWH. The setting is depicted at an agonisingly slow pace:

Then the glory of YHWH departed from over the threshold of the temple and stopped above the cherubim. While I watched, the cherubim spread their wings and rose from the ground, and as they went, the wheels went with them. They stopped at the entrance of the east gate of YHWH's house, and the glory of the God of Israel was above them. (Ez 10:18-19)

This narrative is followed by the nightmarish vision of Jerusalem as a pot in which the victims of the ruling class's violence and finally this ruling class itself are cooked. This scene is connected with the judgment on Pelatiah ("YHWH destroys a remnant"), which contrasts with the prophecy of a new heart of flesh for the exiles, thus for another "remnant" of Israel which may - perhaps not be "handed down". Following this interruption the attention turns once again to the glory of YHWH enthroned above the cherubs:

Then the cherubim, with the wheels beside them, spread their wings, and the glory of the God of Israel was above them. The glory of YHWH went up from within the city and stopped above the mountain east of it. The Spirit lifted me up and brought me to the exiles in Babylonia in the vision given by the Spirit of God. Then the vision I had seen went up from me (Ez 11:22-24)

It almost seems as though the "glory of YHWH" stops once again to bid farewell before definitively vanishing from the temple and thus from the earthly world, that is, to disappear from the human sphere. We have to read through many more chapters of the Book of Ezekiel to discover that the glory of YHWH returns to the temple (Ez 43:4), but this theme remains tied to a visionary future that, like the new Jerusalem in the Book of Revelation, points beyond terrestrial space-time. 


\section{Excursus: Schelling's Attempts to Rediscover the Divine Addressee}

This overthrow of the symbolic order prompts us to wonder whether the end of the world might go hand-in-hand with the end of prayer and with the vanishing of the divine throne and the glory of YHWH from the human field of vision. They appear to have been replaced by an infinite melancholy, traces of which we can detect in present-day pop music but also in great popular narratives and mythologies of the twentieth century such as Tolkien's The Lord of the Rings. ${ }^{5}$

One philosopher, in particular, has struggled against this loss with tremendous intellectual vigour, though it is probably no coincidence that there is no definitive edition of the key texts in which he strives to salvage the divine palace. I am referring to Schelling, who as a forerunner of Kierkegaard, Rosenzweig, Pareyson, and the personal-dialogic works of Buber and Ebner, struggled in what is known as his "positive philosophy" for a God to whom one can pray ${ }^{6}$. Hegel was identified by him as his paradigmatic adversary in this regard. He believed Hegel had sublated the division between earthly and heavenly world, still viewed in Kant's work as the dichotomy of freedom and nature and of the moral and physical world, into a dialectics. At this point I would like to devote a brief excursus to Schelling, though I am keenly aware that there is no space to examine his philosophy exhaustively. ${ }^{7}$ But we make a brief digression in mentioning it here, because, despite its intellectual magnificence, it exemplifies, in my opinion, the failure of restoring the heavenly palace of God back into the human field of vision on the basis of old notions of direct access to the divine.

Catholic Theology from A. Günther through H.U. von Balthasar to W. Kasper gratefully embraced Schelling's "attempt at God", though they have often tried

5 Tolkien's Middle Earth is a world abandoned by the gods, who have created an insurmountable intermediate space between their residence and the earthly realm. This is why, despite the book's religious foundation, there are no prayers and the gods merely return, as embodied in Gandalf and Saruman, in a transformed, weak and ambivalent form. The associated loss, symbolized especially in the doomed elves, lends this work a profoundly melancholic atmosphere, which may have helped make it one of the most-read and most-discussed books of the twentieth century.

6 A special position is occupied here by Cacciari who, very much like Schelling, strives to imagine the history of the human being. How far even the God of prayers is from being involved in this history would be worth its own investigation. In any case, see I. Guanzini, Lorigine e l'inizio. Hans Urs von Balthasar e Massimo Cacciari, Pisa 2012.

7 I tried to provide a precise reconstruction of the idea of God in Schelling's late philosophy in: K. Appel, "Personalität und Alleinheit Gottes. Versuch einer Deutung der Schellingschen Vernunftekstasis", in: K. Müller and F. Meier-Hamidi (eds.), Persönlich und alles zugleich? Theorien der Alleinheit und christliche Gottesrede (Fides et ratio), Regensburg 2010, 81-100. 
to pass over his provocative aspects and forced Schelling into a theological framework anchored in traditional metaphysics. ${ }^{8}$ Thus their intellectual efforts generated little of a truly novel character. Twentieth-century theology in particular then inserted Schelling's trinitarian ideas, and those of Hegel, into the trope of an often hypertrophic trinity of love - without "forgetting" to admonish Hegel for being overly attached to temporal reality.

Schelling's Philosophie der Offenbarung ("Philosophy of Revelation") has been available for some time now in the clearly structured and readable original version, evidently corrected by Schelling himself. ${ }^{9}$ In light of the originality and sophistication of his ideas, but also his profound efforts to get to grips with the Kantian critique of reason and religion, I believe this text, if read in conjunction with the Darstellung der reinrationalen Philosophie ("Outline of Purely Rational Philosophy"), is superior to many contemporary theological attempts to think about God. It deserves to be seen as one of the most serious and brilliant attempts to conceptualize the personal God of prayer. But there is a problem in Schelling's late philosophy, namely that of language and the associated approach to the issue of God. Despite the insights generated by Kant's transcendental dialectic and despite the experience of the "lack of God"10 (Hölderlin), Schelling tries to achieve direct access to the absolute through his doctrine of potencies. ${ }^{11}$

At the end of the Darstellung der reinrationalen Philosophie, informed by the trope of Kant's transcendental ideal, Schelling arrives at the concept of the absolute. As the "being actu Actus", it is characterized by the fact that it is "placed beyond its concept", 12 and thus "emerges as the true (existing) lord of being (of the world), as the personal, true God". ${ }^{13}$ This conception is underpinned by the idea that, through its realization as idea in individuo, the transcendental ideal rejects itself as all-encompassing unity (omnitudo realitatis). It absolves itself of its own rationally accessible concept of the highest essence.

8 Kasper criticizes Schelling's idea of the trinity, for example, for its overly historical connotations. See W. Kasper, Das Absolute in der Geschichte. Philosophie und Theologie der Geschichte in der Spätphilosophie Schellings, Mainz 1965.

$9 \quad$ F.W.J. Schelling, Urfassung der Philosophie der Offenbarung (2 vols) (Philosophische Bibliothek 445), Hamburg 1992.

10 See J. Deibl, "Der Entzug heiliger Namen”, in: Theologie und Philosophie 4/2011, 523-550.

11 See K. Appel, Zeit und Gott. Mythos und Logos der Zeit im Anschluss an Hegel und Schelling, Paderborn 2008.

12 F.W.J. Schelling, "Darstellung der reinrationalen Philosophie", in: Schelling, Sämmtliche Werke. Ed. by Karl F. August Schelling. First section: 10 vols. [=I-X]; second section: 4 vols. [=XI-XIV]. Stuttgart and Augsburg 1856-1861: Cotta. XI 253-572, here 563 . 
For Schelling, the God of prayer, for which he coins the succint phrase "person seeks person", ${ }^{14}$ demands an ekstasis of reason, that is, the cessation of reason's attempts to locate itself through theoretical and practical encounters with the world..$^{15}$ This is associated with a kenotic turn away from the peculiar universality of reason towards the radically singular, which is what the God of Eschaton would be - a God never to be apprehended by reason.

The question, however, is whether Schelling's work contains any equivalent of the multifarious linguistic ruptures that Hölderlin sought to bring into poetry, Hegel into dialectics through the trope of double negation and later Heidegger, Derrida and Badiou into thinking the event. Through the trope of reason's rational self-sublation for the sake of the dignity of the contingent sphere, which is the vital frame of reference within which personal prayer can occur - what kind of prayer would merely express general and unaddressed thoughts? - Schelling departs from the highways of classical metaphysics. But we might wonder whether his philosophy undermines its own goals by falling back on metaphysical issues and figures of thought, which are distinguished by a direct orientation of thought towards being, a being conceptualized as presentable and whose essence does not lie in any relocation or displacement. An example of this tendency, occuring particularly in Schelling's Weltalterphilosophie (Philosophy of ages of the world), is the desperate search for first causes, for principles and for a positivizable beginning, something that Kant has problematized in his transcendental dialectic.

Conversely it might be objected that in his positive philosophy, contrary to unmediated access to being as defined later by Heidegger and his followers as the "metaphysics of presence" or "ontic thought in light of presence", Schelling pursues a consistently eschatological approach. This orientation finds expression in sentences such as "The starting point of philosophy is thus that which will be, in other words the absolutely future dimension". ${ }^{16}$ Schelling's philosophical language, however, ultimately aims directly at the coming God, who will have been brought to presence. This may entail a failure to fully consider that in post-Enlightenment times the heavenly palace is concealed and that even for many people who have retained their faith, or remnants of it, God himself can no longer directly be localized either in language or in the spaces and eras of our world.

\footnotetext{
14 F.W.J. Schelling, "Darstellung", XI 566.

15 There are thus good reasons for A. Franz's suspicion that Schelling's ideas here are close to those of St. Augustine. See A. Franz, Philosophische Religion. Eine Auseinandersetzung mit den Grundlegungsproblemen der Spätphilosophie Schellings, Würzburg 1992. 
For the question arises whether God does not have to be "liberated" from a metaphysically understood beginning. The sympathy apparent within theology for the "big bang" seems to involve a desire to preserve a kind of metaphysical remnant, but attempts to build on theories of this kind seem highly fragile, as evident not least in natural scientists' present-day efforts to rid themselves of the "big bang". Has the first being vanished from the horizon, a being that has steered the world since eternity? Following the disconnection of the heavenly palace from the immanence of the worldly context, doubts arise as to whether a direct line, be it as causa prima or as the transcentental foundation of being, runs between heaven and earth. Last but not least, even the question becomes problematic as to whether and to what extent the logos actually encapsulates reality or leads at a void. ${ }^{17}$

The current deep crisis of both Protestant and Catholic theology, which no longer seem to have anything to say to the world, and (within the Catholic realm) the crisis of Eucharistic worship, which was once the heart of the Catholic faith, seem to be two of many symptoms of the loss of a locatable God. The same goes for the effort, evident far beyond Catholicism, to encounter God in sites of pilgrimage in order to preserve the localization of prayer, at least in places of singular renown. With the loss of the intersections of heaven and earth, our conception of space and time is also becoming ever more leveled out and virtualized because it lacks a center and features nothing but selfdissolving peripheries.

There are two critical issues that require illumination. The first is the price/ prize/praise of mortality ${ }^{18}$. It is in fact prayer, as will be developed below, that runs counter to the idea of a fusion of finite subjects with the infinite (whatever this may mean in concrete terms) subjectivity of God. To put it another way: when prayer is addressed directly to God without detour or relocation the idea of union with the divine seems to hold sway. But when the addressee can no longer aim directly at his other but can reach him only via the detour of selfrelocation, the idea of a departure from the self as center of power (from the self as the first person) arises, and thus the idea of mortality. In the first section of this book the accent lay on the price that the human being must "pay" for its vulnerability. This contrasted with the desire to make a bet with God, to be able to gain immortality by one's own efforts and to turn this bet into a driving force of history, even at the price of a relapse into meaningless nothingness. In

17 See K. Heinrich, Von der Schwierigkeit nein zu sagen, Frankfurt / Basel 1982.

18 As already stated at the beginning of the book the word "Preis" in the German title "Preis der Sterblichkeit" implies both the price that a thing costs and the prize of honour that one receives, and thirdly, the praise that one gives to somebody. 
this last part, after the passage through the crisis symptoms of language (Deibl) resp. of the symbolic orders (Guanzini), an accent should be placed on "praise", on the fact that prayer is also an experience of de-subjectification, posing the question of whether prayer is not in fact also praise for the gift of mortality (see chapter 3$)$.

The second key issue is the temporal form of prayer. It was pointed out in my first essay that the temporal form of Christianity is an anachronistic one, that the Christian does not coincide with any era but exists within the displacements and ruptures of history. An essential expression of this was under the heading of "epilogue", which expressed the fact that Christian existence begins at the point where historical tropes have run out of steam, where even the contrast between death and life can no longer claim validity as an ultimate reality, where the world as it previously was is obliterated, that is, left behind and reconfigured. With reference to Musil and thus building on part one, but also taking into account the contributions of Deibl and Guanzini, it is the aim to tease out how prayer is bound up in an essential way with the "devaluation of all images" and with the new symbolic order to which this gives rise (see chapter 5).

In light of the key insights sketched above, in the following survey it will be aimed to provide a detailed interpretation of two Bible passages, namely Psalm 36 (chapter 3) and Mk 6:30-46 (chapter 5), which are punctuated with philosophical reflections (chapter 4 and chapter 6). With the aid of these texts light will be shed on paradigmatic acts of prayer, not least in order to give us the space to examine the addressee and content of prayers. The many different forms of prayer and its various facets cannot be exhaustively addressed. But it will be demonstrated how much prayer and new humanism, as well as prayer and the speaking of God, are mutually entangled. This affirms the pleasing idea expressed, among others, by J.B. Metz, that theology is first and foremost a speaking to rather than a speaking of God. ${ }^{19}$

\section{Prayer as Evocation of the Divine Name and Glorification of YHWH} (Ps 36)

One of the most remarkable psalms in the Psalter, the great Book of Prayer of Israel and the Church, is Psalm 36. It contains profound reflections on the essence of prayer. I refer the reader here to the outstanding interpretation of

19 See the key remarks by J.B. Metz on prayer in: J.B. Metz, "Ermutigung zum Gebet", in: Metz, Mystik der offenen Augen. Wenn Spiritualität ausbricht, ed. by J. Reikerstorfer, Freiburg 2011, 98-114. 
this psalm by N. Lohfink. ${ }^{20}$ The following translation of Ps 36 thus borrows from his:

1 To the choirmaster. Of David, the servant of YHWH

2 The whispering of infidelity to the sinner -

(it speaks) within the space of $m y$ (own) heart.

Never (is there) any fear of God (elohim)

before his eyes

3 For he has flattered himself (too much) in his own eyes (for) his iniquity ('âwōn) to be found out, (so that it might be) hated.

4 The words of his mouth (bring) mischief (against the poor) ('āven) and deceit (mirmāh);

he is no longer capable of willing good through wisdom.

5 Thus he will (continue to) plot mischief while on his bed, to travel a way that is not good, and will not reject evil $(\mathrm{ra})$.

6 O YHWH, your faithfulness/grace (chesed) (reaches) to the heavens, your trustworthiness ('emûnāh) to the clouds.

7 Your righteousness (zedāquāh) like (as far as) the mountains of God, your judgments (mišpāt) (press as deep as) the great primeval flood, human and animal you constantly rescue, o YHWH.

8 How precious is your faithfulness (chesed), o God (elohim), so that all people take refuge in the shadow of your wings.

9 They feast on the fat of your house, and the river of your delights (Eden) - from that you permit them to drink.

20 See N. Lohfink, "Introspection and Cosmic Mysticism. Psalm 36", in: In the Shadow of Your Wings: New Readings of Great Texts from the Bible. Translated by L.M. Maloney, Collegeville 2003, 98-110. See also E. Zenger, Dein Angesicht suche ich. Neue Psalmenauslegungen, Freiburg / Basel / Vienna 1998, 82-9o; T. Lorenzin, I salmi, Milan 2001. 
10 For with you is the fountain of life; in your light we see light.

11 O continue your faithfulness (chesed) to those who know you, And your righteousness to those of upright heart.

12 May the feet of pride not tread upon me, or the hand of the sinner drive me away.

13 There the practitioners of evil lie prostrate (35:8);

they are thrust down (35:5) and unable to rise (35:11).

Ps 36 builds on the preceding psalm in two respects. First, Ps 35 ends with the supplicant vowing to murmur the glorification of YHWH all day long, which is then realized in Ps 36 . Second, at the start of Ps 36 , David is referred to in the singular as the servant of $Y H W H$, which establishes a direct connection to Ps 35:28, in which David is identified through this terminology. A contextual link can also be observed in the fulfillment of the promised glorification in Ps 35, and second through the theme of enemies. In Ps 35, as in sub-collection $35^{-41}$ as a whole, the topic of persecution is to the fore. The supplicant of Ps 35 is confronted with a superior force of malicious and arrogant enemies out to kill him. In Ps 36 the situation worsens in the sense that the enemy who was rallying his forces against the worshiper in Ps 35 has moved even closer.

The place in which hostility is now to be found is in fact one's own heart. It is from there, "offshore", that we hear a perverse oracle featuring a melange of guilt, violence against the weak and poor, treachery and wickedness. All the external enemy's characteristics that harried the worshiper in Ps 35 have moved inwards, such that the adversary described there emerges as the projection of the supplicant's own mind, emotions and affections.

The world in which the speaker of Ps 36 finds himself has shrivelled down to a tiny speck: the self-immured heart. In this constricted space there can be no room for any alterity. It is filled up entirely with the "self" and its projections. These, moreover, can no longer be recognized as such - because there is no possible place of self-distancing. In German the fear of God can be conveyed by the word Ent-setzen, which expresses a disturbance in the very redoubt in which man has settled in order to shut himself off from his surroundings. So what is now occurring throughout the day is not the glorification of YHWH indicated in Ps 35:28 but rather a total - spatially as well as temporally -seamless, immanent machinery of self-ish malignancy that knows no "outside" and no depth. One can add the observation that the four denominations of evil project the 
four ends of the earth onto the soul, thus reinforcing the impression of something that is closed off. It is hard to imagine a more powerful expression of Augustine's "incurvatus in se".

With this flourish the psalm might have reached its end. But it continues. To be precise, the first part right after the title (v. 1), which in four verses sketches the aforementioned utterly depressing scene, is followed by two other parts along with a kind of epilogue. The third portion, like the first, consists of four verses and thirty-six words, so that the psalm exhibits a clearly framed center. This generates the following structure: The heading in verse 1 , which extends the narrative arc to the preceding psalm, is followed by the first main section, which depicts the internally contorted heart as the precant's true enemy (vv. 2-5). Between this and the third section - as I have mentioned, both use thirty-six words as well as the term "God" (elohim) - the actual center of the psalm, consisting of two verses and sixteen words, is inserted.

The central section of the psalm begins immediately with the tetragrammaton YHWH and also ends with it. In analogy to the four words used to describe the enemy in the first section, four words are selected to represent YHWH, namely faithfulness (grace), trustworthiness, righteousness and judgment. Notably, the avowal of the righteousness of YHWH fulfils the promise made in Ps 35 to murmur his righteousness all day, while also establishing a close relationship to the supplicant himself who, in Ps 35 , grants joy to those who want his righteousness (35:27).

So while there was an immense chasm between YHWH and the worshiper in the first section, in the second section a new relationship is established. This is all the more remarkable because there is no path leading from part one to part two. The divine name entails a totally new approach, for even if the tetragrammaton is the location of an appeal, the supplicant of the first part is not its initiator. In the first part there was a sober account of the situation of the self-incarcerated sinner, from whose heart emerged a non-locatable voice of the breach of faith. The second part radically alters the entire scenario: It is a different voice that arises and interrupts the external description as well as the oracle of self-projection from vv. 2-6.

This different voice, which relies on the unsayable tetragrammaton whose call begins with an interruption of the voice, a pause, a silence and an awareness of the unsayable, expands to assume a cosmic angle of vision. Instead of the four words manifesting the self-contained perspective of the oracle at the center of the heart, a new immeasurably broad landscape comes into view. God's communion extends far beyond the earthly realm to heaven, his trustworthiness to the clouds. After the visible panorama has unfolded upwards, the same thing happens with the architecture of the cosmos. Righteousness 
extends to the mountains of God, and here we should think not just of their height but also of their roots, which extend infinitely deeper even than the immense roots of the trees.

The next step creates a connection between space and time. The mountains' immeasurably deep fundaments are further deepened so that they extend all the way to the primeval flood on which the whole world, including the mountains, is built. The gaping chaos of the old world is touched by the law of God and stripped of its power of death, as the next sentence indicates: "human and animal you (constantly) rescue, o YHWH". The spatial horizon of the voice extends to that which "is" beyond all being. The same applies to the temporal horizon, which transcends the sphere of death as the deepest expression of the boundless chaos, insofar as YHWH rescues everything from it. This salvation extends not (only) to the supplicant, or Israel, or humanity, but encompasses every living thing. With the evocation of this force of rescue, which pervades the cosmos from "heaven" to the "primeval flood", in other words from eschaton to proton, the hymn to YHWH reaches its climax and can pass into the renewed enunciation of the nameless name. Between God and God or, better, between YHWH and YHWH, the entire cosmos is paced off and becomes a part of praise that culminates in the confession of saving grace for the sake of all mortal existence.

In the third section the addressee shifts. It is no longer the explicit name of YHWH that is invoked, but the general appellation "God" (elohim). Thus, what follows, is a supplement to a sequence that is already self-contained. After the silence necessarily associated with the tetragrammaton, a new appeal to God begins. The motif of faithfulness (grace), which already introduced the form of the name of YHWH in the central section, is singled out here. This leads the worshiper to two crucial places that enable him to recall himself through a recapitulation of history. The first is the temple in Zion featuring the cherubs, whose wings shield the human being, the second the Garden of Eden. Here we shift from God's comprehensive expansion throughout space into the vast realm of time. The third part opens with the eschaton. At the end of days, as we know from Isaiah and Micha, human beings, far beyond Israel, will flood to Zion and thus to the temple as the place of the cherubs.

This image is indicated in v. 8 before immediately turning into the proton in the next verse. The specific wording of this passage - "stream of joys" evokes the name "Eden", in other words the Garden of Paradise. Temple and Paradise are connected through the motif of the shared meal, in other words the feast, which extends from eschaton to proton. In v. 10 the feast is associated with the life and light of God. God is the sun of righteousness, radiating through the entirety of the cosmos all the way down to the primeval flood, in 
other words to death-pervaded Sheol. But the crucial point seems not to be simply a rescue from death, as Lohfink thinks, but rather the Cosmic Feast, which signifies precisely Divine salvation that reaches to death. So it is less a matter of salvation from death than the incorporation of death into the great feast, which leads to the fountain of life and the vision of God. It is of decisive importance that this vision is no longer experienced by the isolated heart immersed in the prayer, but by a "we" that binds the worshiper to Israel, to all humankind, to all life, and to God Himself.

The last two verses of the third part, which again revolve around motifs of the beginning (heart, righteousness, sinner), return to the topic of knowledge. God is to extend his fellowship to those who know him. If we consider the intimate dimension of this verb (jedah), which in Hebrew also means sexual intercourse, it becomes understandable that one of the purposes of the Psalm is the worshiper's and - in light of the "we" - the mortal world's intimate fellowship with God. In the opening the worshiper knew nothing of this mortality - "Never (is there) any fear of God before his eyes" (v. 2) - and he imagined himself to be untouchable and invulnerable. In contrast, having been ousted (ent-setzt) from his own opaque self-reflection by the divine name, the worshiper can now bring his mortal existence into fellowship with God and celebrate this ousting. However, the worshiper is still warned about the pride that lurks before the heart of arrogance, threatening to overwhelm him as it did for Cain. The "driving away" that might occur at the hands of the sinner (v. 12) is reminiscent of the expulsion from paradise, which is executed this time by the proud heart itself, which considers itself to be invulnerable.

The final verse (v.13) seems to be an inorganic conclusion. It corresponds to the heading (v. 1 ) within the symmetrical structure of the psalm. The words "lie prostrate", "thrust down" and "rise" forge an even closer link with the preceding psalm $(35: 5,8,11)$. But more significant is that the breaking of those who do not know death takes place in a "there", which brings us to the second enigmatic core of the psalm. The first was in the center and referred to by the name of YHWH, which framed this center as addressee and interrupted the first part. In the closing verse the reader of the psalm is confronted with the fact that the "there" cannot be placed anywhere. It may refer to the temple and to paradise or to the fellowship with God. But if we consider the function of v. 13

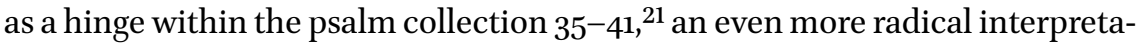
tion suggests itself, one that is crucial to the dynamics of the prayer: the "there" refers to the entire psalm or to the psalm collection as such, that is, it points to the act of praying itself. At the beginning we could hear the placeless voice

21 See E. Zenger, Dein Angesicht suche ich, 88-9o. 
of the perverse oracle, whereas here the voice is, so to speak, the voice of the text, of the Psalter itself. It is the voice of "heaven" - the heavenly palace in which the Psalter is sung, making it the true location of heaven or, if we look more closely at the psalm, the place in which heaven, earth and the primeval flood come together and the self-reflecting subject is dis-placed and set free.

The psalm identifies two enigmatic points that must be related to one another and are linked by the motif of rescue, namely the tetragrammaton YHWH and the "there". The latter refers to the divine name, which is the focal point of the prayer, the entire Psalter and the world assembled there. The heavenly palace can thus arise precisely because of the opening of the heart, which is set in motion by the voice of the Psalter and is aligned with the divine name. This name, however, persists as a rupture within the text and manifests itself through the collapse of the proud subject that imagines itself to be immortal. As a result, the entire psalm, at least on a canonical reading, tends towards a silence, one that indicates the prayer's ultimate destination. The prayer builds up, so to speak, an overwhelming excess of images and yet takes leave of them through the "eloquent" silence of the divine name, which indicates the death of all the worshiper's conceptual worlds and into whose intimacy the precant returns. Here the name of YHWH is linked with glorification, which is no longer uttered by the old, isolated subject of the supplicant, but by a different voice that sublates the first.

\section{Openings: Leibniz, Kant and Hegel or Openness as Monad, Self-Affecting and World-Encounter}

Psalm 36 transports the worshiper to the limits of the cosmos which has been separated from all images and projections, opening up the possibility of prayer beyond introspection and manipulation. The question, that, therefore, arises is whether within the cosmos, within the symbolic order of our time, there is a place for the opening and interruption that YHWH signifies. The second chapter addressed the work of Schelling, who sought to tease out the singularity of God.

Following the thought trajectory of Psalm 36, one could say that Schelling is ultimately concerned with the final revelation of the name of $\mathrm{YHWH}$, which is associated with the end of being, whether as a subject or as a substance, but that he perhaps avoided the ultimate consequence of this rupture for language and thought. In this section we enter into a dialogue with Leibniz, Kant and Hegel. There is one thing that all these thinkers have in common, namely their rejection of the naturalistic narrative of the world which was already underway during their era. 
This narrative is bound up with the disappearence of the heavenly palace. It is an account without true past or future, a narrative that unfolds in the immediacy of meaningless now-moments. Post-modernity was characterized as the end of grand narratives but what confronts us now is perhaps the most monstrous story of all eras, namely the extinguishment of the universe through entropic hypothermia. Dawkins \& Co. - or should we say the conglomeration of atoms that are then given the functional designation of Dawkins, etc? - are carrying on a tradition that ultimately goes back to Zeno, Plato and a specific reading of the dialogue Parmenides ${ }^{22}$ and extends all the way to modern nihilism.

To paraphrase Heidegger, we are dealing here with the tradition that determines being as presence. ${ }^{23}$ Hegel's suspicion, alluded to in part one, that the final narrative of the Western world would be an all-"nullifying" nihilism, found its political confirmation, much more than in the reign of terror unleashed by Robespierre and the French Revolution, in the all-encompassing terror of National Socialism. Like no other ideology before or since, National Socialism embraced pure annihilation, and thus a "positive nothingness" became the ultimate purpose of existence. ${ }^{24}$

Today we are confronted with a different sort of nihilism, namely a nihilism of temporality. Time here has no telos of any kind, either in the shape of an anticipated future or a past worth remembering. The interchangeability of its moments is matched by the virtual emptiness of our consumer world, in which every object has become arbitrarily replaceable and treatable and reduced to its ghostly image.

The philosophical background of temporal nihilism is the transformation of the timeless being postulated in Parmenidean metaphysics, which was conceptualized as an eternal, unchanging and absolutely self-present and static

22 See K. Heinrich, Parmenides und Jona, Basel / Frankfurt 1992. Conversely, see H.D. Bahr, Zeit der Muße - Zeit der Musen, Tübingen 2008.

23 In Being and Time Heidegger ruptures this classification through the structure of care and by consistently reflecting upon the primacy of the future. His account of an apresent time in his late work On Time and Being is even more radical. That a thinker of this calibre, to put it cautiously, sympathized at least on occasion with the most positivistic nihilism of all previous times, namely that nihilism in which nothingness, as absolute annihilation, becomes the thing in itself, is hard to grasp. But it demonstrates that we must never regress, theologically or philosophically, to the point of abandoning Kant's intellectual achievements and his philosophy of morality and freedom.

24 In no way am I claiming that nihilism is the only way of explaining National Socialism. There are many modern nihilisms and many different forms of meaninglessness, and there are many factors and developments of a political, economic and cultural nature that led to the National Socialist disaster. But National Socialism would have been unthinkable without the modern form of nihilism. 
now, into the perfect self-presence of the machine. In "Zenoic" fashion, the pre-requisite for this self-presence is the divisibility of time into numerous motionless now-points, which are amalgamated to form a seamless causeeffect relationship. There is no moment here that is not absolutely determinable and objectifiable, and there is no moment that could point beyond itself. Shifts, displacements, apertures, or overlays have no place here; everything is perfectly presentable. The atomized moment knows no scope for meaning and is therefore entirely unutterable, insofar as every linguistic meaning manifests itself only in the shadings, associations, and "blurring" of the expression. In the first part of the book, it was suggested that bodies are always ex-oriented in their mutual references, that they represent subjects radically opened to the other and that their openings generate a kind of "second skin" as the sphere of their significance. In contrast, machines are entirely disembodied and devoid of any opening towards the other and thus without transcendence and meaning beyond the immediate moment.

This self-contained world subsists as a conceptualization of being that is a conglomeration of absolutely quantifiable and determinable objects, and as well as a sequence of events strung together as arbitrarily contiguous moments. This generates a mechanistic history of the object-world extending from the "big bang" to the end of all structures through a postulated protonic decay in the year $10^{35}$, or also with the "evaporation" of the last black holes beyond $10^{100}$ years. Since every structure can be traced back to particles and their interactions, there is ultimately no ontological distinction or peculiarity, but at most quantitative degrees of each entropic state.

In contradiction to this world of objects whose absolute determinability and nakedness abolish every meaningful symbolic order, the subject essentially represents a disruption, rupture and displacement. The subject does not recount its history as the repetition of the past from a later vantage point. Instead the past is constantly reconfigured and contextualized as well as reimagined. It is in fact an ontological prejudice of the present day, shared by both the historical and the natural sciences, that there is a past as such in the first place. This is not just a matter of asking ourselves how far we can approach an objectifiable past, one whose existence is already taken for granted. Even more radically, we must ask whether something like the past has any ontological consistency or whether it derives its meaning and its being only within the pertubations and refractions of our subject-like symbolic worlds. We can of course write down and consolidate the past (or pasts) in the form of texts, but again it is only the reader who, in the reception of texts in ever new ways, brings this past (these pasts) to life and casts a vision of it. 
Even in his early writings, Hegel did not regard the world as an objectifiable space-time into which a subject might be inserted. Rather, in his view, the world is fundamentally intersubjectively mediated. The point of departure is the subject-subject-object relationship rather than the subject-object relation. Our object-world is therefore never to be regarded as independent of intersubjective relationships. Subjects cannot be reduced to objects, as Leibniz already demonstrated and as Kant brilliantly set out later in the paralogism chapter of the Critique of Pure Reason. Leibniz realized that we never arrive at inner units on the basis of an object-world. We will, as he concludes in the simile of the mill, "only find parts that push one another, and we will never find anything to explain a perception [content of consciousness K.A.]". ${ }^{25}$

Our contents of consciousness, therefore, only become meaningful if they are already constituted as units of significance, which can then also be dissected in a further step ("parts that push one another"). In the realm of our experience, according to Leibniz, we find one paradigm for such inner units, namely subjects. For this reason, the world is not an accumulation of mechanistic objects that are spatiotemporally "external to one another", but is instead a world of subjects that "temporalize" and "spatialize" themselves through their respective world relations.

Every monad is an infinite world of relations in which other monads are "perceived", that is, "reflected and mirrored". A human subject perceives other human subjects, the sun, other living beings, such as a beetle. These in turn perceive the human beings and so on. From this perspective, space and time can no longer be detached from, and are not independent of subjects and their acts of cognition and perceptions. Rather, they are the expressions, or schema, of the relations that constitute the subject (and are constituted by this subject) or paraphrasing Deleuze, ${ }^{26}$ that (are) "unfolded" (by) the subject. The crucial point is that in Leibniz's work the infinite differentiations, in which we encounter the world, are an expression of the dynamic relations of monads so that they always have a subject-like focus. This means that Descartes's res extensa does not exist independently, but is a specific form of expression of monads, in other words of the res cogitans, whereby "cogitans" here expresses not only the conscious act of thinking, but rather the subject-like "unity-background" of

\footnotetext{
25 G.W. Leibniz, Monadology, Indianapolis, §17/7o.

26 See G. Deleuze, The Fold. Leibniz and the Baroque, Minneapolis 1992.
} 
every entity, regardless of whether it is self-conscious, alive, or just plain matter (stars, etc.). ${ }^{27}$

Kant goes beyond Leibniz - through steps which cannot be described in detail here ${ }^{28}$ - by demonstrating that the manifold relations of the monads can be constituted only through an infinite explanatory regress within the monad, even though such a regression inevitably leads to antinomies. According to Leibniz the monad's relations are sufficiently constituted, if the monad is infinitely "permeable" to all other monads, with this infinite permeability being provided by the singular and all-encompassing subjectivity of God and his affirmation of the world. According to Kant, however, this step towards the infinite means either an interminable, never concludable extension of the finite, or, alternatively, a leap into a no longer definable otherness (the infinite sphere). In both cases, the finite as such is no longer predicable, but is instead "lost" either in this infinite regress or through the above-mentioned leap. The prerequisite for taking either step would be to exceed the bounds of our spatiotemporal experience, which Kant calls an "exuberance".

Conversely, the philosopher from Königsberg presents the world neither as a mechanistic structure (the atheist-materialist "solution") nor as a subject (the pantheist Spinozan-Leibnizian ${ }^{29}$ "solution" in the sense that God is the only subject and the only reality). In Kant's work the concept of the atom and the subject is replaced by that of synthesis. In every act of perception and thinking a connection is made that corresponds to that of subject-predicate and thus the structure of judgment. The true location of this "synthesizing" is the "productive synthesis of the imagination", in which a synthesis (between understanding and time as form of intuition) takes place that manifests itself in creating the time-series (it produces time; Zeitreihe), the content of time (it fills up time; Zeitinhalt), the order of time (temporal relations; Zeitordnung) and the sum total of time (the correlation between time and object;Zeitinbegriff). ${ }^{30}$

In this sense the synthesis is neither subjective nor objective, insofar there is no subject that produces time. Yet neither is there any time existing "in

27 The question of non-living units in Leibniz's work would require in-depth discussion. I can only note here that in those spheres in which cosmic bodies generate their own gravity we would surely have to refer to monads from Leibniz's perspective. See H-D. Klein, System der Philosophie II: Naturphilosophie, Frankfurt, etc 2006.

28 See K. Appel, Zeit und Gott, 65-72. See also: B. Liebrucks, Sprache und Bewußtsein IV. Die erste Revolution der Denkungsart - Kant: Kritik der reinen Vernunft, Frankfurt 1968.

29 The final point made in the Monadology is that the finite subject is by definition the selfperformance of God. See K. Appel, Zeit und Gott 6if.

30 See I. Kant, Critique of Pure Reason, B 184f., translated by Paul Guyer and Allen W. Wood, Cambridge / New York / Melbourne 1998, 276. 
itself" independently of these determinations. The result of Kant's idea here, as notably highlighted by Heidegger, ${ }^{31}$ is the establishment of an inseparable connection between subject, form of judgment and time. "Subjectivity" refers to synthesis, to time as schema of the productive synthesis of the imagination, to self-affecting. This last term is of key importance. It points the way to the Kantian understanding of time and hints at semantic bridges to the work of Leibniz, Hegel and to the topic at issue here. According to Kant, the "form of intuition [...] can be nothing other than the way in which the mind is affected by its own activity, namely this positing of its representation, thus the way it is affected through itself, i.e., it is an inner sense as far as it regards its form". ${ }^{32}$

Between the "activity of the mind", that is, between the positing of its representation and the receiving of this representation, there remains a hiatus, no matter how small. There is an unbridgeable gap between the act of positing and the representation of it, which is why representing not only consists of the active moment of affecting, but - equally - signifies being affected. Time is precisely this interval between activity and passivity, this difference that unfurls in every act of self-affecting. It is not simply the drawing of a line within the mind as a continuous act of self-affecting, but displacement and delay within the play of affecting and being affected, activity and passivity. This means that time cannot be sublated into the activity of conceptual synthesis ("judgment"), and remains the transcendental point of reference (as a form of intuition, that is, as the difference into which the synthesis of judgment is formed) of every activity of understanding, by which the subject is constituted. In other words, in Kant's philosophy the subject emerges as the process of synthesis, though this synthesis does not unfold in an absolute sense as in the work of Leibniz (where God is the absolute bond between all monads and thus the absolute synthesis), but is structured around an absolute non-reflectable difference and thus concretisizes itself as time. The breathtaking consequence of this idea is that time cannot be conceptualized within an anaffective "space", but is due to the game between "affecting" and "being affected", which contrasts radically with any purely materialistic and objectifiable view of being.

Also in Hegel's work the subject is constituted around a point of difference. Hegel's novel idea, already addressed in his Early Theological Writings, consists in emphasizing intersubjectivity as the unfolding of this point of difference. For the subject can only affect that difference which it $i$ itself as the difference between singular and universal (for example, in the case of language

31 See M. Heidegger, Kant and the Problem of Metaphysics, Bloomington 1997.

32 I. Kant, Critique B 67f., 189. 
which is the individual idiom and the universal medium of communication). ${ }^{33}$ Hegel's early writings try to conceptualize this idea through the category of love ${ }^{34}$ which is one of two possible forms of unity (synthesis). The first synthesis is the subjugation of the world through the subject's own reflexivity, as typical of the modern subject-object schema in which differences are subjugated to the subject's will to unify and homogenize. To this end the subject detaches itself from the natural and social ties in which it was embedded and tries to assimilate the world that is separate from it. To be able to do this the subject must render the world finite, objectify it, make it manageable, abstract it from its original connection with the subject, divest it of its difference and "comprehend" it.

In his early theological writings Hegel makes the important statement that "To comprehend is to master. To animate the objects is to make them Gods." 35 While the first part of this sentence characterizes synthesis as subjugation, the second part conceives of synthesis as love. This is not a matter of the invention of gods, but of the experience that the self cannot apprehend itself as an object (as the master of its own doppelgänger), that self-experience can only arise out of the indisposable other, i.e. that point of difference in light of which time must be conceptualized. Love expresses in these early writings of Hegel a subject-subject-object-relationship, that is a primordial synthesis of aliveness, as the most intimate form of relatedness within the difference(s) of the united life. Only because the subject is opened to the other, which encounters in its transcendent relationship in a subject-like mode (and not as mere object), it can exist and perceive itself as a subject. The subject designates an affective space of being in which affecting and being affected are mutually dependent on each other. Like Leibniz, Hegel too universalizes this relationship. Strictly speaking, the subject can come to speak only through subject-like encounters, through the "united life", because it is only the other that gives meaning as a subject. Pure objects would be "mute".

33 Departing from the model of self-affecting, P.A. Sequeri develops his ideas in light of the notion of a pro-affecting between Father and Son, whose point of departure is the relational moment. See P.A. Sequeri, "Nur einer ist der Gute. Theologie der Affektion als Umkehr der Ontologie”, in: E. Arens (ed.), Theologie trifft Ästhetik (QD 246), Freiburg 2012, 46-72.

34 See K. Appel, Entsprechung im Wider-Spruch. Eine Auseinandersetzung mit dem Offenbarungsbegriff der Politischen Theologie des jungen Hegel, Münster / Hamburg / London 2003; I. Guanzini, Il giovane Hegel e Paolo. L'amore fra politica e messianismo, Milan 2013.

35 Hegel, Frühe Schriften (Werke 1), in: G.W.F. Hegel, Werke 1-2o (stw 6o1-62o), hg. von E. Moldenhauer und K.M. Michel, Frankfurt/Main 1986, 242. 
Therefore, in Hegel's theological writings, then, God is not to be thought as the highest souvereign detached from the world, but as love, as the subjectlike and affective space, in which world-encounter takes place. This encounter oscillates between self-gain and self-loss. The "self" finds itself in the unity of the other. But it is precisely in the unity of the other, that the self gains itself as subject via an act of self-loss, through a supplement, an infinite difference that it cannot appropriate: "The most intrinsic unites itself in the touch, in the feeling up to unconsciousness, the suspension of all distinction [...]."36 In this sentence Hegel is alluding to the sexual encounter as the paradigm of love.

What takes place here is an opening towards an opening, an opening that is no longer reflexively accessible. The absolute merger and sublation of all distinction must not be understood in the sense of the first synthesis as the integration of the other, but rather as its release (insofar as there is no longer "something" to distinguish, but merely the subject as difference from itself and thus pure openness). Through the formation of this radical openness, in which the two openings exchange and meet hospitably, the miracle of birth, the "becoming of aliveness", occurs. According to Hegel, then, the truth of the subject and its world is the opening of the other, and of the being within the sphere of radical openness, as embodied by the child. That is what is meant when Jesus urges us to "become like children" (Mt 18:3). God as love is radical openness that can be called time. As indicated when discussing the work of Kant, it is time that characterizes the openness of our existence, or the difference constitutively inscribed in our existence.

Birth, child and life do not refer to "something" but are in fact the absolute openness of the world, being towards the other. Rather than the relationship between two objects or even the relationship of a subject to an object, "being" is understood as the opening of life to its other or, better, as opening towards the openness of the other. Within this opened-up space life is embodied as the hospitable exchange of affecting and being affected by the no longer positivizable other. It is in this very movement of opening that prayer comes into play as the semantic expression of this radical opening. What is happening here is neither a matter of addressing myself to a delimitable other that is localized and thus positivized by me, nor the self-referential turn of the subject towards itself. Instead, the subject "becomes-other-to-itself". Linguistic spaces, one's own and those of others, upcoming times, both past and present, are opened in prayer towards this other, preparing His arrival, which may occur in the form of a child or even a contingent event.

$3^{6} \quad$ See G.W.F. Hegel, I 248. 
God is revealed through the openness of a given world-encounter, which excludes the possibility of unmediated access to him. This intellectual path, on which Hegel struck out in his early writings, is continued in a consistent and systematic way in the Phenomenology of Spirit and the Science of Logic. While Hegel's lectures discuss positive contents, it is fair to say that these major works of him are developments of the sphere of openness outlined above. In the first part of the book I briefly sketched the approach taken by Hegel's Phenomenology and tried to show how, up to the chapter on spirit, consciousness seeks to find itself in its world, in other words to position (imagine) itself within it, while in the chapter on religion self-consciousness grasps and symbolizes itself as a negative other. The second negation would then be difference in itself as pure transition, as oscillating movement and texture of references, that which is radically open to itself, within which Hegel "locates" speculative philosophy.

The point of departure is neither a positivizable being, nor a delimitable subject, nor even a "self", but rather that which unfurls itself and creates space within itself, which is encountered in the name YHWH and entails an opening of our symbolic order.

\section{Prayer as Opening and Re-Creation of the Symbolic Order (Mk 6:30-46)}

Following this second philosophical excursus, another dimension of prayer will be considered in this chapter, namely, prayer as the reconfiguration and opening of our symbolic order. J.B. Metz emphasizes that the "language of prayers remains full of painful discretion" and "does not condemn the addressee to respond"37. J. Reikerstorfer notes that "the lament even more than the affirmative language of praise and thanksgiving preserves the unapproachability of God himself". 38

Both theologians locate prayer in the context of the remembrance of suffering as an experience of resistance against injustice, distress and apathy. It is important that prayer challenges the existing symbolic order of our world as well as our thinking and does not call on God to legitimize it, but confesses his name in seeking to change it. In order to explain how prayer is to be understood ontologically as the beginning of a new world, as a departure from the eon of closure, I would like to draw on an event that has a special meaning within the

37 J.B. Metz, Memoria passionis, Freiburg 20o6, 98.

38 J. Reikerstorfer, Weltfähiger Glaube. Theologisch-politische Schriften, Vienna / Berlin $2008,181$. 
Bible, namely the so-called "multiplication of the loaves". How incongruous this title is remains to be explained. This event is told in all the gospels, and no less than twice in Matthew and Mark. Mk 6:30-46 is the basis of the analysis in what follows.

The apostles gathered around Jesus and reported him all that they had done and taught. And he says to them, "Come away by yourselves to a desolate place and rest a while." For many were coming and going, and they had no leisure even to eat. And they went away in the boat to a desolate place by themselves. Now many saw them going and recognized them, and they ran there on foot from all the towns and got there ahead of them. When he went ashore he saw a great crowd, and he had compassion on them (lit.: and the entrails twisted around him), because they were like sheep without a shepherd. And he began to teach them many things. And when it grew late, his disciples came to him and said, "This is a desolate place [desert], and the hour is now late. Send them away to go into the surrounding countryside and villages and buy themselves something to eat." But he answered them, "You give them something to eat." And they say to him, "Shall we go and buy two hundred denarii worth of bread and give it to them to eat?" And he says to them, "How many loaves do you have? Go away and see." And finding out, they say, "Five, and two fish." Then he commanded them all to lie down, group by eaters, group by eaters [sic!] on the green grass. So they sat down in groups, by hundreds and by fifties. And taking the five loaves and the two fish, he looked up to heaven and said a blessing and broke the loaves and gave them to the disciples to set before the people. And he divided the two fish among them all. And they all ate and were satisfied. And they took up twelve baskets full of broken pieces and of the fish. And those who ate the loaves were five thousand men. Immediately he made his disciples get into the boat and go before him to the other side, to Bethsaida, while he dismissed the crowd. And after he had taken leave of them, he went up on the mountain to pray. ${ }^{39}$

The context of this pericope is the sending forth of the apostles (Mk 6:7-13). They return from their work and are completely exhausted from the teachings they have conducted. What is initially evoked in this context is the constitution of Israel (and of the church) as a learning community in the Deuteronomic tradition. The substance of this teaching, as the gospel according to Mark underlines, is the Kingdom of God. Jesus impresses upon his followers this doctrine not just intellectually, but also inject it into the innermost fibres of the body. If the "authority" over impure spirits is repeatedly underlined in this context (e.g. Mk 6:7), this is because the old symbolic order that dominates the linguistic, physical and social body is perceived as "demonic", i.e. deeply hostile to life, disorienting and destroying personality. In the center of existence forces emerge that lead people into the abyss of death and isolation. 
Jesus relieves his twelve collaborators of their burden by instructing them to rest. When the crowd persists in pursuing them, he even performs the teachings himself. His motive leads to the center of what is meant by the Kingdom of God. He allows himself to be seized by the assembled crowd's misery and need. Or, to put it out more precisely, he allows their confusion to be felt in his very inner beings, "into his innards". This expresses a key predicate of God, which extends into the internal sphere of the name of YHWH, namely his compassionate care for his people. The injuries, distress, and confusion of the crowd pierce to the innermost sphere of Jesus's body which becomes as the resonant space of these sufferings in its entirety the place of God and thus the new heavenly palace of the divine court. God himself has thus transposed his old Oriental residence of heaven or the temple, where heaven could touch earth, into the resonant space of a body in which the suffering of the people resounds and a site of compassion and mercy can be carved out.

This setting is crucial to the following remarks. In place of the ancient geography of heaven, temple/cult and earth, the body of Jesus emerges as the concrete continuation of the Old Testamentary prophetic geography, focused on YHWH's compassion extending all the way to the "divine entrails". The palace of God as a frame of reference for the sacred symbolic order is transformed in a common space of affectivity, ${ }^{40}$ a space which finds concrete expression in the teachings and the life of Jesus and those who follow him. The tremendous strain caused by this reorientation of the previous world is immediately made clear to the reader of the gospel. The twelve apostles enter (after having taken a rest?) the scenery, noting - in temporal terms - the evening hour, which is the hour subject to death (v. 35). Spatially, the attention is drawn to the "remoteness/desert-like character" (v. 35) of the place where Jesus is active. The "desert" or "remoteness" ( $\dot{p} \eta \mu \circ \varsigma$ ) conjures up another association. It is the place of demons and thus the ancient locus of disorientation in which the subject is destroyed.

With apparent logic, then, the twelve urge Jesus to send the people, in other words the expanded throng of disciples, away so they can buy something to eat (v. 36). But they also seem anxious to go to the "villages", to return to civilization, sparing them from exposure to the demonic threat of the desert. The previous, sinister symbolic order of civilization is rendered null and void in the basileia of Jesus, but this is not consolidated to the point where it can withstand the threat of the desert. 
In his comprehensive commentary on Mark ${ }^{41}$, B. Standaert attempts to show, with great sensitivity, that this gospel was read on Easter night and was intended to bring about the final transfer of catechumens into the eschatological Christian community. The gospel is indeed a radical change in the symbolic order of knowledge and life, a change which, if we follow Standaert, initially leads, via baptism, into a life-threatening desert, before arriving on Easter morning in the eschatological community of the Church. Something similar occurs in this pericope. The crowd has begun to receive the teaching of Jesus, but it would as yet be dangerous to leave them alone in the "desert".

So the arguments put forward by the twelve are not only concerned with necessary nourishment, but also with the question what can be reasonable for the crowd. What they disregard is the fact that the crowd's return to previous social conditions (the villages) also poses a great risk. The danger lies in the futility of previous attempts of teaching and learning, together with the threat of a return to the "fleshpots" of Egypt with their inherently inverted and inhuman orders. As B. Standaert notes there are good reasons why the text - through the injunction that people return to their homes - alludes to 1 Kings 22:17. In this passage such a return is bound up with the sad fact that the scattered crowd no longer has any "master", in other words no frame of orientation. ${ }^{42}$ Jesus does not respond directly to the suggestion made by the twelve, but instead directs their attention to "eating". The twelve had been so busy teaching that they did not even "have leisure to eat" (v. 31). Much the same goes for the crowd, which is why Jesus instructs the twelve to "give them something to eat" (v. 37). This establishes a connection to 2 Kings 4:42-44, where the prophet Elisha saves the prophetic disciples from most dire hunger, thus proving himself the representative of the "Lord", which is in itself an indirect response to the twelve. Their question, "Shall we go and buy two hundred denarii worth of bread ..." (v. 37) highlights the earlier subtle hints of the risk of a futile exodus from the old symbolic order. Within two verses (v. $3^{6-37)}$ the word "buy" is used twice by the twelve in connection with eating. The peril is that the kingship of God, which must remain the point of departure and destination of teaching, will be replaced by the domination of money, which threatens to become the key criterion of the people's well-being. It is at this point that the reader is furthest away from the prayer's addressee. "These people" seem "to have no master" (1 Kings 22:17) who could make a turn from the order of exchange and the economy of give and take.

Jesus does not embrace this logic, rather responds with the question "How many loaves do you have?" and the two imperatives "Go away" and "See" (v. 38).

41 B. Standaert, Marco. Vangelo di una notte. Vangelo per la vita. (3 vols), Bologna 2011.

42 See B. Standaert, Marco, 383. 
The latter injunction, or both injunctions taken together, imply that a shift of perspective is in the offing. This shift gradually begins to emerge: the first vision brings to light two fish in addition to the five loaves. The text thus steers us away from eating as simple ingestion towards a true meal (or feast). While the number of loaves, like that of the fish, is laughably small, the sphere of the bread and thus of the immediate satisfaction of need is nonetheless surpassed. Of great importance is the next command in which Jesus directs the "crowd" to sit down on the green grass in groups (v. 39). Two levels of meaning are thus evoked. First, the transition from the disorderly crowd to the grouping of the people is an important step in the Exodus (cf. Ex 18). But even more important is the reference to the "green grass". So far, it has always been the desert in which the narrative unfolds, but the grass now signals a shift of perspective. Our attention is directed to a view that is able to open up the previous marginal existence to new life perspectives.

The following verse, v. 41 , conveys the crucial turnaround. What is not depicted in this verse is Jesus performing the multiplication of loaves. But Jesus's words and deeds do profoundly echo the Eucharistic event, which is evoked by the sequence "taking", "blessing", "breaking" and "giving", which is interrupted only by the view up to "heaven", from which YHWH fed his people with manna during the Exodus. Analogous to the celebration of the Eucharist, a transformation takes place within this sequence and analogous to the feeding with manna a preparation for the Exodus commences. Contrary to the common exegetical scheme often used in the case of the multiplication of the loaves, in the crucial verse we are immersed into Jesus's prayer, which is referred to, in extremely abbreviated form, through the word "blessing" and the above-mentioned allusions. This opens up a tremendous creative power capable of changing the textual setting utterly. What Jesus creates here is an entirely new landscape. This is characterized by abundance and a festive mood. As in the Eucharistic transformation, where the order of being shaped by bread and wine morphs into the veritable body of Jesus, the reader is seeing here a transformation of the demonic desert into the eschatological, that is, festive gathering of God's liberated people. Time passes into the seventh day.

It is important to remember the starting point of this narrative. The entire scene is set in motion by Jesus allowing himself to be shaken to his very viscera by the wounds of the "old" world, his sensitivity rendering him the voice of YHWH. The union Jesus-YHWH expands in time in the pericope cited here, stretching from the Exodus (feeding with manna) to the Eucharistic feast of the basileia. There is also a great spatial arc from Jesus through the twelve and the crowd to heaven, and also a qualitative one, ranging from the desert and its bleakness through the green grass to the plenty of bread and fish. The image of poverty turns to one of plenty. The new symbolic order, that of 
the kingdom of God, is characterized by unlimited creative power - the creation of a new, nourishing world along with an affectivity in which the divine name is realized through the person of Jesus.

The decisive moment goes far beyond a request-and-receive schema of prayer, for the entire world is transformed through and into the creative word of blessing. Of course the question of the historicity of such a scene imposes itself because it automatically raises the question what is to be expected of prayer. Two interpretations, which are usually regarded as opposed, fall short. We can neither say that the sign of the bread should be understood allegorically without having nothing to do with objective-physical reality, nor would it be correct to conceive of it in a narrowly historical sense as if it were a documentary film on Jesus. Rather, it is all about an entirely new symbolic order, one behind which there is no "other" objectifiable reality, but which cannot be abstracted from the actors as well as the listeners and readers of the event.

The place of the prayer is wherever old symbolic orders are shattered while opening doors for new ones, those in which the creative power, joy and sensitivity of the social and individual body are able to emerge in a deeper way. What is required is thus the "devaluation" of all images that have accompanied and constituted the previous world in order to create it anew. At this point the transition of images leads to a change in the temporal setting. The miracle of Jesus's feeding links the manna miracle of the Exodus to the Eucharistic feast of the eschaton. The reader is thus faced with the radical occasion of the feast itself, in which previous temporal instances are suspended and the interlocking chain of cause and effect is fractured.

This brings out the skilfulness of Mark's account: at no point is Jesus portrayed as the one who "multiplies" the loaves and the fishes, thereby becoming simply a causal agent among others, and it is this that opens the eyes for an eruption of exuberant and free creativity, which is no longer measured by the necessities of what is past, but instead creates an entirely new symbolic order. The tremendous difficulty associated with this shift of perspective is evident in the gospel itself. Not long after this scene Jesus's closest disciples once again ask him: "But where in this remote place can anyone feed them (the crowd) with bread?" (Mk 8:4). In 9:16, finally, the disciples "discussed [...] with one another and said, '[...] we have no bread'. Unless we don't want to think of them as extremely stupid, which would scarcely be compatible with the subsequent history of Christianity, we will have to acknowledge that diving into a world that goes much deeper than the world of our sensory and affective desert and is freer than the being of a seamless causal relationship is human beings' most difficult task of all. In this view, prayer does not lead merely to an objectively, or subjectively, perceived new world. Instead, the coordinates are reset so radically that an entirely different mode of understanding is required, 
namely an opening that extends into the viscera, one that allows us enter into the world of the miracle.

It is perhaps in this light that the closing sequence must be understood as well: Jesus bids farewell to the crowd, which is now equipped for a new way of seeing and hearing and is released into its responsibility as the people of Exodus, and he concludes the entire narrative with a prayer, because even for him this radical openness and creativity is possible only in a constant correlation with the life-giving symbolic order of the Father.

\section{Prayer as Translation of the Subject}

Jesus's bond with the Father is portrayed in a very special way in the Gospel of John, in which, characteristically, Jesus's words to his disciples transition into a prayer to the Father (Jn 14-17). Jesus emphasizes, as this gospel states, that, "The words I say to you I do not speak on my own authority" (Jn 14:10). This sentence expresses something that pervades prayer in both the Bible and the Church, namely a displacement and translation of the subject.

At the beginning of this part the idea of the heavenly court was mentioned. The biblical palace was presented as God's court, populated with angels, with one of their main tasks being, in addition to the glorification of God, bringing terrestrial prayers to God. This is radicalized to the point that entire congregations (see the Book of Revelation, in which the letters to the seven churches are addressed to their angels) as well as individuals have their own angels representing them in heaven. "See that you do not despise one of these little ones. For I tell you that their angels in heaven always see the face of my Father in heaven" (Mt 18:10), as Jesus teaches his disciples.

The centrality of the representative prayer pervades the entire Christian tradition. One person prays for another, the living for the living, the dead for the living, the living for the dead, the dead for the dead, angels for the living and dead, and so on. Theologically significant is the fact that the dogma of the Trinity has its origin in prayer, not in ontological notions (like the idea that God is in Himself relationship). This is not so much a matter of the potential to direct Christian prayer towards Father, Son and Holy Spirit or that prayer speaks in the name of the triune God. More importantly, the Christian act of prayer is generally performed "in the Spirit through the Son to the Father". If we look at the Psalter, then once again, from a Christian perspective, the worshiper prays through the mediation of Jesus, David, the Spirit, and even Israel.

But what is the significance of this characteristic structure of prayer? Might it help shed light on what Jesus means by the precept "do not keep on 
babbling like pagans, for they think they will be heard because of their many words" (Mt 6:7)? This question leads us to an as yet unaddressed issue, namely translation. If prayers are said in the Spirit through the Son to the Father, there is at least a twofold translation and shift of the praying subject before the prayer reaches its addressee. The significance of the entire heavenly court, of the representation in prayer that this household provides, particularly through entities that are impalpable such as the dead, angels, etc., seems to lie in the very fact that the praying subject is constituted before God as a translated subject. One might say that in prayer the voiceless subject becomes its own voice - or the voice of the other - and receives orientation, transforming itself from a self-contained being to fundamental openness. "[We are not] unaware of this remarkable possibility that is the very possibility of language, therefore that of our being [thus] the very possibility of the world", ${ }^{43}$ writes J.L. Nancy in his book Adoration on this connection between prayer and openness to the world. Besides that, however, the fundamental transformation of the subject's voice and orientation is also of key importance. This is a further, radical intensification of Hegel's idea of the subject as "becoming-other-to-itself".

In prayer the subject brings the world into language, places the world and itself in an intersubjective space and orients this space towards a radical indisposable openness, towards the other of its self. Thus, in prayer a differentiated dialectic of subjectification and de-subjectification occurs (or we might also say a subjectification as the dialectic of loss of self and gaining of self). From Lacan we know that the unsent letter still reaches its addressee. ${ }^{44}$ For every instance of "self-expression" always also means having turned to the "great other", that is, to the symbolic order into which the subject is placed and from which it receives its recognition, orientation and language.

Human subjectivity occurs through the dialectic of individual and universal, of speaking and being spoken. To put it in more forcefully, the human subject consists in the assumption of one's own status as posited, of being addressed, of being through the other, of the indisposable and unavailable opening suffered by the other. It is a response to recognition that has been granted or denied. Its action and speaking has been the action and speaking of the other. Within this being the intersubjective relationship is exceeded, especially if it were conceived as symmetrically contoured by other individuals, since every individual subject was already a recognized and spoken subject in the first word and in the first gesture. Prayer provides a response to the word that has

43 J.L. Nancy, Adoration: The Deconstruction of Christianity II. New York 2012, 3.

44 J. Lacan, "Seminar on the 'Purloined Letter", in: Lacan, Écrits, translated by Bruce Fink, New York 2007, 6-48. 
already constituted the subject both consciously and unconsciously, though it should be underlined that response and demand are not to be understood in a chronological-causal sense, but occur synchronously: There is no word (Wort) without response, no response (Ant-Wort) without word.

Before returning to de-subjectification through prayer, it should be stressed that the meaning of prayer is not exhausted in a response to an opening and in addressing oneself towards the other. Prayer must also not be understood predominantly as an action of the praying subject. G. Lohfink is right in his criticism that modern-day prayers are often not invocations of $\mathrm{God}^{45}$, but are instead concerned with the action of the worshiper. The problematic aspects of his book on prayer - which bears a questionable title, in that prayer does not simply provide a home (as if YHWH could ever be our home ...) -, are the idea that prayer enters into the "conversation that God himself is",46 and also that Lohfink conceives the communication between man and God too directly. When reading his book, in which commendable exegetical observations are connected with a highly traditional theology of prayer, one wonders whether the problem of prayer for modern humanity can be simply traced back to a lack of moral effort, or a lack of religiosity. Lohfink seems not to have realized that the unmediated access to God has become profoundly problematic, and it would be interesting to hear his view on what happened to all the unanswered prayers that characterize our epoch so dramatically. Did the worshippers simply not pray enough? As far as the divine conversation of the trinity is concerned - into which, according to Lohfink, the precant is supposed to enter - one might add sarcastically that, thank God, at least within the Trinity the realization of the ideal communicative community, invoked so often in a German culture with such tremendous faith in language, can be witnessed ...

Against such views, the element of de-subjectification in prayer can be highlighted. This moment must not be contextualized within familiar mystic tradition to the extent that the worshiper engages in the prayer of the Holy Spirit and thereby leaves behind his contingent, empirical existence. Rather, attention must be paid to the fact that the subject's desubjectivation means that the content of the prayer will never directly make it to the one to whom it is directed, especially if we are to assent on Lacan's dictum that "a letter always arrives at its destination" 47 , and if we bear in mind that "the signifier's

\footnotetext{
45 G. Lohfink, Beten schenkt Heimat. Theologie und Praxis des christlichen Gebets, Freiburg 2010, 66 .

46 G. Lohfink, Beten 25.

47 J. Lacan, Écrits, 3 o.
} 
displacement determines subjects' acts, destiny, refusals, blindnesses, success, and fate". 48

Jesus is reported to have made the unsettling remark that a belief, like a grain of mustard seed, is all we need to tell a mountain: "Move from here to there', and it will move. Nothing will be impossible for you" (Mt 17:20). Apart from the always possible allegorical interpretations, the idea could rise in this saying that it was about a miracle of shift and displacement, in which case the mountain would become almost incidental. The core of the prayer lies, as already adumbrated in the interpretation of Psalm 36 , in the very fact that the divine name displaces and shifts the word. Against this background, we might perhaps understand the entire gospel according to John as one great prayer manual, since Jesus repeatedly appears in it as the one who strangely deflects the questions and the desires of his interlocutor while never offering direct answers. So the essence of prayer is not that God responds directly to a request, but that the request itself undergoes a relocation and shift through prayer. Even in the intercessory prayer the Christian cannot simply take the place of the other, because this would mean that the other becomes the reflection on one's own desire. He can only take the place of a deplacement, carry out semantically this preliminary shift, in which the Other becomes the subject at all.

Hence, prayer is not characterized by a linear cause-effect relationship. Indeed, it seems pretty absurd to consider myself as the "cause" of the fulfilled wish of the other. Because I have prayed for you, God has done this or that for you. It would be just as odd to put the fulfillment of a prayer down to my way of praying (its form, intensity, my moral integrity). The institution of priesthood can probably be traced back in significant part to the hidden knowledge that prayers are not directly addressable, in the sense that, within his community, the priest is responsible for the translatory activity mentioned above. This necessity to translate prayers highlights the fact that the wish, thanks or praise through which the worshiper opens himself to the other/God will undergo a shift before its possible arrival.

As long as this shift - Guanzini made this point in her discussion of anamorphosis - has not occurred, language remains captive to general images and phantasms. Such language would be the ongoing production of these images, which express nothing personal, certainly not the name of the supplicant, but merely the various imaginative constructs of the overarching symbolic order, which as shown earlier aimed at obfuscating one own's mortality. To express this in more biblical terms, what comes to the fore here are the predominant obsessions ("demons") of the social body in which we are configured. In these "images", language and the aims of prayer would 
dissolve, so that in the end only a self-referential mirror, the virtual surface of abstract desire, would remain, reflecting "nothingness" and extinguishing our contingent individuality.

Overcoming this "demonology" entails a shifting of our supplications (to echo Lacan: in a transition from pleasure to desire) which is the only way that prayer can attain its goal. This goal would then be to receive oneself as an individual through the transcendence of all images and phantasms. Or to put it in theological terms, the purpose of prayer would be subjectification before God. ${ }^{49}$ If love is where our ultimate subjectification is realized, then prayer would be the gift of love, through which we open ourselves up completely to receiving our name, that is, our own unique vocation. Through the translation of our images, this gesture which is the only way that would in turn be bound up with their abandonment. Prayer would thus produce a peculiar emptiness and openness in which the subject would no longer be predicable, but only callable by name: "Mariam!". Receiving the name as vocation would then, as described in John 20:11-18, be the point of departure for a second turn (the first was, let's remember, the turn away from the sphere of the "own" to a willingness to follow one's beloved to the place of death), towards the witness and vision of the Lord ("I have seen the Lord!", Jn 2o:18).

\section{The Prayer: Epilogue}

At the center of Christian prayer is the "Lord's prayer", which calls Christians into the basileia (kingdom) of YHWH. The approach of the basileia is marked by manifold openings, such that Jesus could state: "The blind receive sight, the lame walk, those who have leprosy are cleansed, the deaf hear, the dead are raised, and the good news is proclaimed to the poor" (Lk 7:22). The openness of the basileia was intrinsically symbolized by Jesus's name and the open wound of his body (Jn 19:34). As a result, the taking into the affective space of Jesus's vulnerable body, a compassionate and open body into its very bowels, and the associated narrative landscapes, became the calling of the Christian, who receives his (or HIS) name through this process. This receiving of one's name expresses the special character of prayer, which is rooted in relocation and marked by overlaps and shifts. From a Christian perspective, that name always consists of the superposition of two names (one's own name and that of the messiah), which form an oscillating and never fixable center.

49 See J.B. Metz, Mystik, 110. Here he gives us the fine sentence: "The prayer is the oldest form of the human being's struggle over his being as subject". 
Through the four parts of this book, the authors of this book have attempted to show vulnerability and mortality as primary motifs of the "new" human being and thus of a new humanism. Mortality should not be understood as a transition to "nothingness", but as the loss of all the masks, camouflages, images and forms of protection that characterize our existence. In Being and Time Heidegger rightly highlights the fact that in being towards death we are unrepresentable. In this sense, our mortality also indicates our individuality and irreplaceability.

What remains decisive is the shifting and (self-)displacement of the locatable and objectifiable subject. The object-like dimension of our existence, our positivity, is capable of succumbing to nothing, or, is itself already an expression of it, as it was shown in the context of the Fall. However, if the subject is embodied as a sensitive reference and openness to the other, cloaking itself in a second skin of narratives, signs - Benjamin might say quotations - and ever new porosities, it will be and will remain all the more vulnerable, and this is what endows it with its special form of existence.

But the maximum injury it can suffer would be its reduction to a mere object. Would this mean the annihilation of the subject, or would it rather be associated with the total retreat, the absolute absence of the subject, which would nonetheless entail the spectral presence of a "remnant"? Mortality first of all means the loss of positivity, that is, the loss of the potential to objectify the subject. Precisely because it is not positive, because it is not disposable and controllable presence, the subject can step outside itself; it can feel, touch and be touched. Mere objects can surely never come into contact, each remaining enclosed in its own presence. The subject can die and thus elude a symmetrical frame of reference. There is no indestructible core of the subject, because such a core would in turn presuppose the presence of a positive "something". Also, the subject cannot become "nothingness" if this nothingness were interpreted as an objectifiable void.

The loss of positivity means that the subject cannot be the object of a final narrative. Even those narratives in which we will have received the voice of the subject, his injuries, his touch and affections, can only anticipate the moment of their own departure, because "even the whole world would not have room for the books that would be written" (Jn 21:25). It may be at precisely this point that prayer begins: when the subject has lost its positivity, when it is the entirely open space "between" narratives, when "everything" has been said about it, when its body is permeability to the other, when the images with which it was occupied have been translated into a vocation that is no longer representable, when its voice begins to cross times and spaces, when it has become the praise (price, prize) of mortality ... 